\title{
THE EFFECTS OF TECHNOLOGICAL CHANGES ON THE SECURITY STAFF WORKING IN THE AIRPORTS: A THEORETICAL RESEARCH*
}

\author{
DOI: 10.17261/Pressacademia.2019.1098 \\ PAP- V.9-2019(45)-p.236-241
}

\section{Savas S. Ates ${ }^{1}$, Sinasi Muratoglu ${ }^{2}$}

${ }^{1}$ Eskisehir Technical University Faculty of Aeronautics and Astronautics, Aviation Management, Eskisehir, Turkey. ssates@eskisehir.edu.tr, ORCID: 0000-0003-2462-0039

${ }^{2}$ Officers of Civil Airports Protection and Security Solidarity Association, Airport Security, Eskisehir, Turkey. sinasimuratoglu@hotmail.com, ORCID: 0000-0001-8057-6090

*The research was supported by the Association of Civil Aviation Safety Officers - SiHAGÜVDER.

To cite this document

Ates, S.S., Muratoglu S., (2019). The effects of technological changes on the security staff working in the airports: a theoretical research. PressAcademia Procedia (PAP), V.9, p.236-241

Permemant link to this document: http://doi.org/10.17261/Pressacademia.2019.1098

Copyright: Published by PressAcademia and limited licenced re-use rights only.

\begin{abstract}
Purpose- The purpose of the study is to determine conceptually the effect of technological changes on airport security personnel. Airports have the potential to attract danger due to its strategic importance. Over the last decade, changes in the threat profile have occurred. The main purpose of aviation is to provide service to passengers by creating space and time benefits. The balance of passengers' comfort and safety to be maintained by air depends on the type of threats and the technology used in security. For this reason, large investments have been made in the development of security technology at airports. In this process, small-scale, relatively simple security systems at the airports, large-scale, high-tech systems were introduced.

Methodology- Literature review method was used.

Findings- In order to evaluate the approaches of the airport security personnel to the technological change, the survey study on the openness to technological changes in the literature review was investigated and the main dimensions in this context were put forward. The impact of technological changes on airport security personnel was interpreted and recommendations were made. Considering that human factor is the user of technology, the attitude of individuals towards technology is effective in ensuring airport security. Technological change has had a significant impact on the attitudes, behaviors and mental structure of the employees. Technological change causes many psychological effects such as monotony, boredom, fatigue, stress and anxiety.

Conclusion- The psychological effects of the technological change on the employees were found to be monotony and boredom, stress and anxiety. The social effects of technological change on employees are alienation and inadequacy, education, communication and social relations. The economic impact of technological change on employees is dismissal and job insecurity. In addition, the physical effect has emerged as health problems.
\end{abstract}

Keywords: Security technologies, airport security, technological change, airport, technology JEL Codes: L91, L93, L98

\section{INTRODUCTION}

Increasing technological developments since the beginning of the last century have been developing more rapidly in this century. In the 21 st century, technology has become one of the most influential factors in life (Küçükköseleci, 2009). Technology; is a concept related to shaping goods, materials, the world and nature in contemporary use (Baykara, 2006).

The concept of security was firstly described as "securitas" by Cicero and Lucretius, expressing the philosophical and psychological state of the mind (Brauch \& Brauch, 2003). Airports have a very important place in today's world because of the relocation benefits they provide in a short time. In these days, where the changes are extremely uncertain and fast, the need for security of buildings, which are strategically important, such as airports, and even the growth point of cities, is increasing. The history of airport security shows significant changes in security control processes since the early 70 s of the last century. In this course of time, threat profiles have changed dramatically. Since 2001 , suicide attacks have become a real risk to civil aviation. In the last decade, these changes in the threat profile have made major investments 
in the development of new security technology, together with efforts to facilitate the transportation of passengers by airline. (Hofer \& Wetter, 2012).

\section{LITERATURE REVIEW}

There are many definitions about technology. Technology is also a knowledge of production methods related to an industry, tools, tools and tools used. The most simple and narrow definition of technology is given as knowledge and know-how and experiences required for the production of a good or service. (Dertli, 2008).

It is possible to list some of the important security services at airports as follows: (Kardeş, Yılmaz, Ateş, Sayın, \& Gemici, 2014):

$\checkmark \quad$ Passenger and baggage screening at terminal access control points,

$\checkmark \quad$ Screening of passenger and cabin baggage at the access point of the cleared area,

$\checkmark \quad$ Ensuring security of entrance and exit of parking lot and parking lot,

$\checkmark \quad$ Ensuring the security of the terminal entrance and exit doors,

$\checkmark$ Baggage collection in the baggage collection area,

$\checkmark \quad$ Ensuring the security of the aircraft waiting in the apron against attacks from outside,

$\checkmark$ Dispatching the weapons from the aircraft to the delivery point,

$\checkmark \quad$ Transfer of money or valuables from the aircraft to the designated delivery point at the airport or from the delivery point to the aircraft,

$\checkmark \quad$ Additional security screening and checks in the process of loading passengers and cabin baggage to the aircraft,

$\checkmark \quad$ Taking the passengers to check out the profile and travel documents when boarding the aircraft,

$\checkmark$ Aircraft search and control service,

$\checkmark \quad$ Ensuring the security of cargo buildings and control of cargoes loaded on board.

In the provision of security services at airports, a path towards small, relatively simple security systems, highly discrete, analog and wired, high-tech community's digital, networked, software-oriented and mobile solutions has been followed (Fulghum, 2015).

In this context, some technologies used in airport security around the world are as follows :

$\checkmark \quad$ Micro Channel Plate X-Ray Systems: Unlike traditional X-ray machines, Xray reflects the absorption of different materials, Xray reflective technology, emits $X$-ray beam and measures the radiation propagation and reflections. The most important difference is that organic matter does not absorb most of the X-ray rays, allowing the beam to pass through. On the other hand, reflexive X-ray imaging systems do a better job of distinguishing organic materials because they return a wide range of different chemicals in the materials (Wikipedia, 2019).

Figure 1: Micro Channel Plate X-Ray Systems

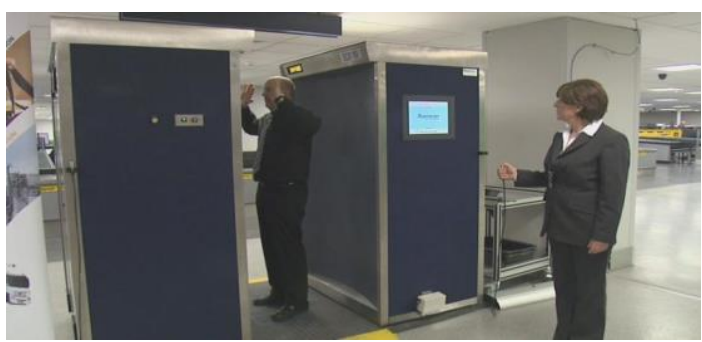

Source: (Rapiscansystems, 2019)

$\checkmark \quad$ 3D Millimeter wave scanners: In response to the growing threat of terrorism, personnel surveillance at security checkpoints, such as airports, is increasingly important. Conventional systems in high-security control points include metal detectors used by personnel and X-ray systems for hand-held goods. These systems are very effective, but there are some shortcomings that need to be addressed. Metal detectors can only detect metal targets such as ordinary guns and blades. Also with these systems glasses, belt buckles, switches and so on. It is not possible to distinguish between simple and harmless substances such as real threats.

$\checkmark \quad$ Millimeter waves penetrate into garments, harmless and reflect on the body; sends signals to a transceiver; the transceiver then sends the signals to a computer at high speed and finally recreates them to create a 3D image (PNNL, 2019). 
Figure 2: Image of a 3D Millimeter Wave Scanner
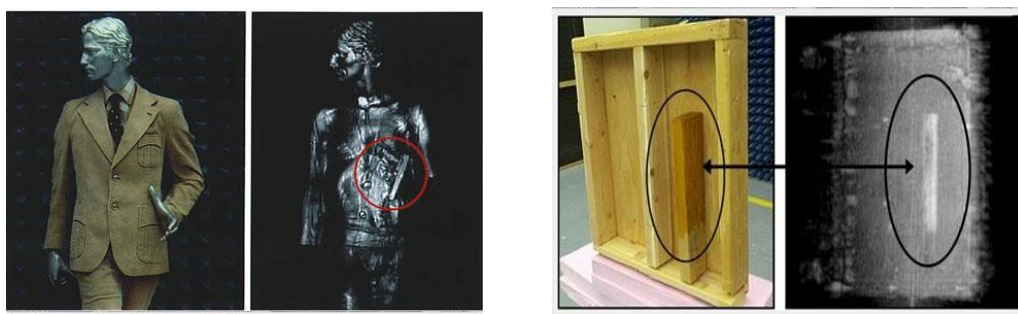

$\checkmark \quad$ Biometric security systems: Biometric systems are the systems that identify the physical and behavioral characteristics of the individuals. (Yalçın \& Gürbüz, 2015). In addition to the employees, biometric systems have been used in some airports for passengers. For example; Privium system using single-eye management for verification of biometric information about passengers at Amsterdam Schipol Airport, London Heathrow Airport, data recorded in passengers' database, IRIS project (iris recognition system) using two-eye iris recognition registered passengers are registered systems (Sasse, 2007).

Figure 3: Biometric Security Systems Used in Airports
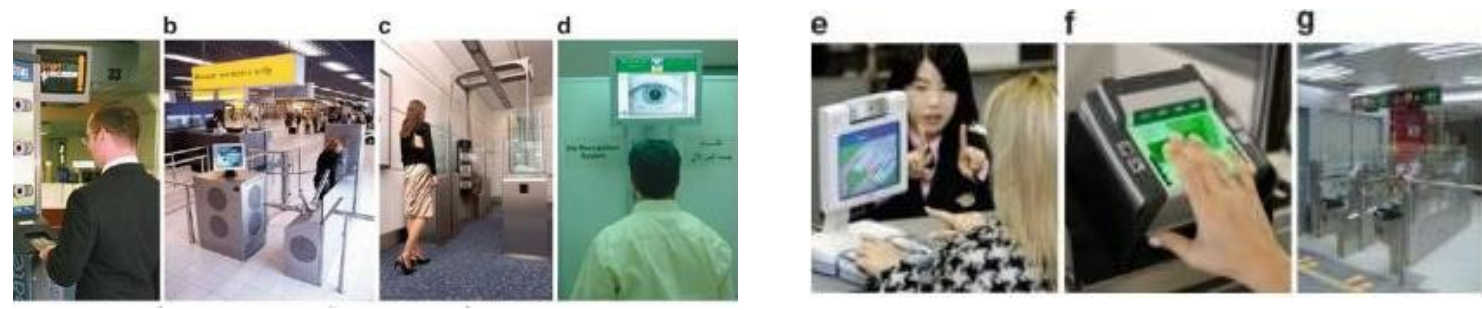

a) Face recognition at Sydney Airport;

b) The iris recognition system at Amsterdam Schipol Airport;

c) Iris recognition system at Manchester Airport;

d) The iris recognition system at Abu Dhabi Airport;

e) Fingerprint recognition system used at airports in Japan;

f) Recognition system used with 10 fingerprints at airports in America;

g) Fingerprint reading system at Hong Kong Airport

Source:(Jain \& Kumar, 2012)

\section{DATA AND METHODOLOGY}

In this study, secondary sources were used for the adaptation of security officers at airports to technological change. Secondary sources include articles, books, postgraduate thesis studies, legal regulations, official websites, announcements and news.

\section{FINDINGS AND DISCUSSIONS}

The attitudes of employees to technology and technological development are largely determined by the technological experience they have acquired in working life (Özmen, 1999).

For example, an $\mathrm{x}$-ray scanner is the most important security device at the airport. However, security personnel guide this device and the threats and dangers are determined by the images reflected on the monitor. In this sense, devices used in today's technology need human guidance (Kardeş, Yılmaz, Ateş, Sayın, \& Gemici, 2014).

\subsection{Psychological Effects on Technological Change on Employees}

It can be said that technological change has a significant effect on the attitudes, behaviors and spiritual structure of the employees. It can be said that the technological changes occur as psychological effects on the workers, monotony and boredom, fatigue, stress and anxiety (anxiety). (Dertli, 2008).

$\checkmark \quad$ Monotony and boredom: The tiredness and frustration of a job at the same pace and repeated repetition are called monotony. Technological changes create changes in the nature and nature of the work, resulting in the formation of monotony. Carrying 
repetition character, lack of revitalizing rest, lack of mobility, routine noise, mental and physical fatigue, non-compliance with work, not getting used to the night shift may reveal the state of monotony (Dertli, 2008).

$\checkmark \quad$ Stress and concern: Stress; it can be defined as physical and emotional reactions caused by situations that impose imposition, pressure and uncertainty. In other words, it is the organism's response to any form of disorder caused by the disturbing environment (noise, coercion, overwork). In this case, stress is the response of each individual to adaptability (Gökgöz, 2013). Work stress can be defined as a non-conformance and a response of the employee because of his / her personal structure and the person's own personality (Erdoğan, Ünsar, \& Süt, 2009). New technology, rapid changes in the business environment, employees' skills are quickly outmoded. In addition, the need to know new equipment and systems constantly well reveals the threat situation in the individual. This would be a potential stressor if adequate training were not provided. Developing technology creates a sense of not being able to work in individuals (Okutan \& Tengilimoğlu, 2002) Technological innovations and a work that does not have the knowledge and experience necessary for them, is in two-sided fear. First; the fear of damaging the machine or the equipment; fear of losing work because it cannot adapt to new technology. In both cases, the individual is under pressure and feels the destructive effect of stress (Dertli, 2008).

\subsection{Social Impacts of Technological Change on Employees}

The social effects of technological change on employees are classified as alienation, inadequacy, education.

$\checkmark \quad$ Alienation: Alienation is a way of putting a person's life into a way of life that does not fit into a life-style or human nature that is contrary to the essence of man (Dertli, 2008). However, the impact of technological change on work alienation will be discussed here. Alienation of work; the reluctance, indifference, frustration, burnout and the inefficiency and conflict that this situation brings together (Gürsoy, 2014). The human has made the division of labor again with technology and the working life is becoming more and more monopolized. Human relations with other people have decreased. Not only the degree of automation in technology, but the technological change in work also affects alienation. Because technological changes are often perceived, as a factor that will lead to the deterioration of the environment, to bring about new risks related to safety and health, to the removal of desires, to the deterioration of social cohesion (Dertli, 2008).

$\checkmark$ Inadequacy: Inadequacy is a situation where those who have come to a certain position do not care about the knowledge and skills required by new technologies. Technology creates a number of works that the knowledge and skill of the employees do not suffice. The introduction of a new invention into the workplace of a machine causes many people to change their positions. The speed at which technological change is achieved causes the wear and tear of the employees. In addition to the danger of dismissal, the inadequacy of the existing technical knowledge and skills of its employees may be the source of unrest. Technological change takes the potential of changing people (Dertli, 2008).

$\checkmark \quad$ Training: To increase the current performance of employees, to update their skills, to solve organizational problems, to make career planning, to keep up with changes and even to guide, the importance of training activities has been increased. Training programs are organized in order to increase and improve the human resources knowledge, skills and capabilities. Technology, automation, changing values, computer, communication, information, environment and organizational changes can be listed as the main factors increasing the importance of education (Örücü \& Yumuşak, 2015). The technological changes in the organizations change the qualities expected from the individual. The changes make the training of the employee obligatory. Because of the change in technology, organizations have to adapt their employees to the machine. Training, jobs and opportunities as they change the work should be able to change itself and skills (Dertli, 2008).

$\checkmark$ Reduction of communication and social relations: Technological change can eliminate the non-formal relationships of staff and colleagues. Some of your friends may be dismissed, some may change parts, or even be wronged.

$\checkmark$ Job dissatisfaction: One of the important changes that technological developments have made in working life is undoubtedly related to job satisfaction (Şahin, Aydın, \& Güler, 2015). Job satisfaction can also be defined as a feeling that an employee experiences because of realizing that his work and achievements coincide with his needs and personal value judgments (Can, 2008).

In high-tech enterprises, job identification forms need to be rearranged. Among them; taking into account the fact that jobs are done faster with computers, reducing work hours, keeping costs at a satisfactory level, and completely acquiring new business segments and business principles (Dertli, 2008).

\subsection{The Economic Effect of Technological Change on Employees}

Technological change is the economic effects on the employees; two are dismissal and job insecurity. The state of weakness in ensuring the continuity of the work under threat. The difference between the level of expected job security and the level of security held; feelings of uncertainty about whether the individual's work will continue; a potential threat to business continuity is the definition of job insecurity. Concerns about job insecurity are accepted as the most severe period of the unemployment process and reveal the situation before losing their job(Çakır, 2007). Because the new technology, different kinds of specialization on the basis of those who work as well as the time they do what they can do their jobs.

\subsection{Physical Effects of Technological Changes on Workers}

Fast technological developments; on the one hand, it serves the welfare of the human being; on the other hand it brings with it dangers for human life and the environment. Electromagnetic waves are spread by many natural and man-made sources, and the impact of work on work environments is inevitable (Dertli, 2008). Because of technological advances, the use of electromagnetic waves is increasing day by day and hence workers are exposed to high levels of electromagnetic waves in their workplaces. Electromagnetic waves emitted by some high- 
tech machines and devices have been shown to cause short-term effects, although not precisely determined to cause problems such as headache or insomnia (Dertli, 2008).

\section{CONCLUSION}

The huge development of the civil aviation sector all over the world creates significant pressure on airspace and airport capacity, which adversely affects the safety of aviation.

Airports, along with other public facilities, are always vulnerable to theft, break-in, or even crimes against the individual. Airports have become the focus of terrorism-related crimes in particular as part of the worldwide air transport system. Such criminal acts include bomb explosion during flight, attacks on airplanes and facilities, and firearms and missiles as well as airplane abduction.

In today's societies, age is the deciding factor in our relations with technology. The effects of technological changes vary according to the profile of the employees. While technological changes are more favorable for young people, these changes are of concern for older workers.

It can be said that there are differences between male and female employees' approaches to technological changes. In recent years, women's place in business life and their interest in new technologies are increasing. The effects of technological change on the young and old workers are parallel to the effects. Because young people who work at the same time, the work time, the older employees (veterans) have more working time. It can be said that the approaches of employees who work at different educational levels are different from each other.

Considering all these, it is important to determine the security personnel at the airports, to what extent the security personnel are affected by the changes of technology. To determine the negativities that the technology has on the airport security personnel, to perform the occupations of the decision-making security personnel, and to prevent the security gaps that may occur in connection with this.

\section{REFERENCES}

Baykara, T. (2006). 21. Yüzyılda Teknoloji \& Teknoloji Yönetimi. Gebze.

Brauch, H. G., \& Brauch, H. G.-S. (2003). Security and Environment Linkages on the Mediterranean Space: Three Phases of Research on Human and Environmental Security and Peace. New York: Springer Verlag.

Can, İ. (2008). Havacılık Güvenliği Açısından Insan Kaynakları Yönetimi ve THY Teknik A.Ş.'nde Bir Araştırma. İstanbul: İstanbul Üniversitesi Yayımlanmamış Yüksek Lisans).

Çakır, Ö. (2007). İşini Kaybetme Kaygısı: İş Güvencesizliği. Çalışma ve Toplum, 1, 117-140.

Dertli, D. (2008). Örgütsel Bir Değişim Olarak Teknolojik Değişime Işgörenlerin Yaklaşımı ve Işgörenlerde Etkisi: Öztay Tekstil (Abbate) Örneği. Kütahya: Dumlupınar Üniversitesi Yayımlanmamış Yüksek Lisans Tezi.

Erdoğan, T., Ünsar, A. S., \& Süt, N. (2009). Stresin Çalışanlar Üzerine Etkileri : Bir Araştırma. Süleyman Demirel Üniversitesi İktisadi ve Idari Bilimler Dergisi, 14(2),, 447-461.

Fulghum, H. S. (2015). Selecting and understanding aviation security systems: Cutting through the marketing hype. Journal of Airport Management, 9, 373-383.

Gökgöz, H. (2013). Stresin Çalışanların Performansı Üzerine Etkisi: Öğretim Elemanları Üzerine Bir Araştırma. Edirne: Trakya Üniversitesi Yayımlanmamış Yüksek Lisans Tezi.

Gürsoy, F. (2014). Sağlık Işsletmeleri Personelinin Işe Yabancılaşma Düzeyi: Van Ili Örneği. Ankara: Atılım Üniversitesi Yayımlanmış Yüksek Lisans Tezi.

Hofer, F., \& Wetter, O. E. (2012). Operational and Human Factors Issues of New Airport Security Tchnology-Two Case Studies. Journal of Transport Security, 5, 277-291.

Jain, A. K., \& Kumar, A. (2012). Biometric Recognition: An Overview. Dordrecht: Springer.

Kardeş, Y., Yılmaz, H., Ateş, S. S., Sayın, A. K., \& Gemici, E. (2014). Türkiye'de Havalimanlarında Görev Yapan Güvenlik Personelleri Üzerinde "Mesleğe Bağlılık Araştırması". INTAVIC, (s. 4-18). Ankara.

Küçükköseleci, E. (2009). Teknolojik Gelişmelerin İnsan Kaynakları Yönetimi Uygulamalarına Etkisi ve Bir Araştırma. İstanbul.

Okutan, M., \& Tengilimoğlu, D. (2002). İş Ortamında Stres ve Stresle Başa Çıkma Yöntemleri: Bir Alan Uygulaması. G.Ü i.i.B.F Dergisi, 5, 1552.

Örücü, E., \& Yumuşak, S. (2015, Eylül). Örgütlerde İşgören Eğitimi Üzerine Bir Alan Araştırması. Atatürk Üniversitesi Iktisadi ve Idari Bilimler Dergisi, 2(19), 235-246.

Özmen, S. E. (1999). Örgüt İçi Değişim ve Değişim Karşısında Birey Davranışı. İstanbul: İstanbul: Marmara Üniversitesi Yayınlanmamış Yüksek Lisans Tezi .

PNNL. (2019, Mart 20). Pacific Northwest National Laboratory. https://www.pnnl.gov/ adresinden alındı 
Rapiscansystems. (2019, Mart 15). EOPLE SCREENING.

http://www.rapiscansystems.com/en/products/ps/productsrapiscan_secure_1000_single_pose adresinden alındı

Sasse, A. (2007). Red-Eye Blink, Bendy Shuffle, and Yuck Factor: A User Experience of Biometric Airport Systems. IEEE Security and Privacy Magazine, 5. Mart 20, 2019 tarihinde http://ieeexplore.ieee.org/document/4218559/ adresinden alındı

Şahin, L., Aydın, E., \& Güler, M. (2015). Teknolojik Gelişmelerin İşin Yapısı ve İşgücünün Nitelikleri Üzerine Etkileri: Hastane Çalışanlarının Algılarına Yönelik Bir Araştırma. Iş ve Hayat, 97-130.

Wikipedia. (2019, Mart 10). Backscatter X-ray. https://en.wikipedia.org/wiki/Backscatter_X-ray adresinden alındı

Yalçın, N., \& Gürbüz, F. (2015). Biyometrik Güvenlik Sistemlerinin İncelenmesi. Düzce Üniversitesi Bilim ve Teknoloji Dergisi, 3, 398-413. 